Gut, 1980, 21, 227-231

\title{
Pancreatic hypofunction in extrahepatic portal venous obstruction
}

\author{
LINDSAY WEBB, G SMITH-LAING, G LAKE-BAKAAR, S MCKAVANAGH, \\ AND SHEILA SHERLOCK
}

From the Academic Department of Medicine, Royal Free Hospital, London

SUMMARY Pancreatic function was studied in 29 patients with extrahepatic portal venous obstruction, and 30 age-matched controls. The aetiology of the portal venous obstruction was known in 20 out of 29 patients. No patient had a history of pancreatitis. Serum trypsin, both fasting and for 120 minutes after a Lundh meal, was significantly lower in the patients than in controls $(\mathrm{P}<0.005)$. $5 / 28(18 \%)$ patients had reduced fasting serum trypsin levels and in 5/14 trypsin was abnormal after a Lundh meal. Mean fasting serum glucose $(3 \cdot 8 \pm 0.49 \mathrm{mmol} / \mathrm{l}$ was significantly higher than in control subjects (mean $3.4 \pm 0.42 \mathrm{mmol} / \mathrm{l})(\mathrm{P}<0.05)$. After $100 \mathrm{~g}$ glucose orally, mean serum glucose at 180 minutes $(5.26 \pm 1.58 \mathrm{mmol} / \mathrm{l})$ was higher than the control value $(3.96 \pm 1.45 \mathrm{mmol} / \mathrm{l})(\mathrm{P}<0.05)$, and 30 and 60 minutes serum $C$-peptide values were significantly lower $(\mathbf{P}<0.005)$. Pancreatic hypofunction found in these patients probably results from an abnormal portal circulation in association with mild pancreatic damage secondary to chronic venous congestion.

Patients with obstruction to the main portal vein, but with normal liver structure, have venous congestion throughout the splanchnic area. The major clinical effect is the development of a portal systemic collateral circulation with subsequent bleeding, usually from oesophageal varices. Deprivation of portal blood flow to the liver leads to mild hepatic dysfunction which progresses as age advances. ${ }^{1}$ The effect of portal venous obstruction on pancreatic function, both exocrine and endocrine, has not been studied in man. We have therefore investigated pancreatic exocrine function by serum trypsin measurements both fasting and after a Lundh test meal, and endocrine function by the plasma glucose, insulin, and C-peptide levels. The effect of portalsystemic bypassing on pancreatic endocrine and exocrine secretions has also been considered.

Results in 29 patients with extrahepatic portal venous obstruction have been compared with those in 30 age-matched control subjects.

\section{Methods}

Twenty-nine patients aged from 16 to 63 years and 30 age matched control subjects were studied. The aetiology of the portal vein obstruction was known in 20 out of the 29 patients (Table ). Liver biopsy

Received for publication 10 October 1979 in all patients showed normal hepatic architecture and blood urea and creatinine levels were normal in all patients and controls. No patient had a history of diabetes or steatorrhoea and only one suffered from abdominal pain. The diagnosis of extrahepatic portal venous obstruction was confirmed by portal venography. The controls were volunteers, medical or laboratory staff, or hospital inpatients with no history of gastrointestinal or endocrine disease.

Fifteen patients and 18 controls, after an overnight fast, received a Lundh test meal. ${ }^{2}$ Venous blood was drawn for analysis of trypsin levels at $0,30,60,90$, and 120 minutes after ingestion of the meal. The serum trypsin was measured by radioimmunoassay (Hoechst RIA - gnost trypsin, Behringwerke, Marburg). In 13 additional patients the fasting trypsin level was measured. Nineteen patients and 12 controls, with no previous history of gastric surgery or endocrine disease, after 24 hours bed rest in hospital and an overnight fast received $100 \mathrm{~g}$ glucose orally. Venous blood was taken for glucose, C-peptide and insulin estimations before and 30,60, 90, 150, and 180 minutes after glucose ingestion. Plasma insulin and C-peptide levels were measured by radioimmunoassay. ${ }^{34}$

In 22 patients the pancreas was scanned by greyscale ultrasonography.

Twenty-six of the 28 patients' weights fell within $10 \%$ ideal body weight, including the 19 patients 
Table Results of pancreatic function in patients with extrahepatic portal venous obstruction

\begin{tabular}{|c|c|c|c|c|c|c|c|}
\hline & $\operatorname{Age}(y r)$ & Aetiology & Fasting trypsin $(\mu g / l)$ & Trypsin (Lundh) & Amylase (Lundh) & \multicolumn{2}{|c|}{ Glucose tolerance test } \\
\hline 1 & 22 & Unknown & 78 & L & $\mathbf{L}$ & $D^{*}$ & $\mathrm{D} \dagger$ \\
\hline 2 & 49 & PRV & 70 & L & $\mathbf{H}$ & - & \\
\hline 3 & 49 & Unknown & 160 & $\mathbf{L}$ & $\mathbf{H}$ & - & \\
\hline 4 & 23 & Umbilical sepsis & 91 & $\mathbf{L}$ & $\mathbf{N}$ & - & \\
\hline 5 & 30 & Unknown & 189 & $\overline{\mathrm{L}}$ & $\mathbf{N}$ & - & \\
\hline 6 & 49 & Cholelithiasis & - & - & - & $D^{*}$ & \\
\hline 7 & 21 & Umbilical sepsis & 182 & $\mathrm{~N}$ & $\mathbf{H}$ & - & \\
\hline 8 & 63 & TPM & 283 & $\mathrm{~N}$ & $\mathbf{N}$ & - & \\
\hline 9 & 19 & Unknown & 205 & $\mathrm{~N}$ & $\mathrm{~N}$ & $\mathbf{N}$ & \\
\hline 10 & 22 & Umbilical sepsis & 290 & $\mathrm{~N}$ & $\mathrm{~N}$ & $\mathbf{N}$ & \\
\hline 11 & 25 & Umbilical sepsis & 205 & $\mathbf{N}$ & $\mathbf{N}$ & $D^{*}$ & \\
\hline 12 & 18 & Unknown & 212 & $\mathbf{N}$ & $\mathrm{N}$ & - & \\
\hline 13 & 21 & Umbilical sepsis & 162 & $\mathbf{N}$ & $\mathbf{N}$ & $\mathbf{N}$ & \\
\hline 14 & 46 & Unknown & 398 & $\mathbf{N}$ & $\mathbf{N}$ & - & \\
\hline 15 & 23 & Neonatal septicaemia & 194 & $\mathrm{~N}$ & $\mathbf{N}$ & - & \\
\hline 16 & 49 & Unknown & 350 & $\mathbf{N}$ & $\mathbf{N}$ & - & \\
\hline 17 & 29 & Umbilical sepsis & 120 & - & - & $\mathbf{N}$ & \\
\hline 18 & 31 & Umbilical sepsis & 123 & - & - & $\mathbf{N}$ & \\
\hline 19 & 31 & Appendicitis & 129 & - & - & $\mathbf{N}$ & \\
\hline 20 & 20 & Liver abscess & 137 & - & - & $\mathbf{N}$ & \\
\hline 21 & 38 & Appendicitis & 235 & - & - & $\mathrm{D}^{*}$ & $\mathrm{D} \dagger$ \\
\hline 22 & 60 & CBD fibrosis & 183 & - & - & $\mathrm{D}^{*}$ & \\
\hline 23 & 52 & Abdominal trauma & 220 & - & - & $\mathrm{D}^{*}$ & \\
\hline 24 & 16 & Unknown & 180 & - & - & D* & $\mathrm{D} \dagger$ \\
\hline 25 & 25 & Appendicitis & 195 & - & - & $D^{*}$ & \\
\hline 26 & 20 & Choledochal cyst & 150 & - & - & $\mathrm{N}$ & \\
\hline 27 & 16 & Exchange transfusion & 200 & - & - & $\mathbf{N}$ & \\
\hline 28 & 25 & Cholelithiasis & 215 & - & - & $\mathrm{N}$ & \\
\hline 29 & 22 & Unknown & 245 & - & - & $\mathbf{N}$ & \\
\hline
\end{tabular}

PRV : polycythaemia rubra vera. CBD: common bile duct. TPM: thrombophlebitis migrans. L:value 2 standard deviations below control mean. $\mathrm{M}$ : value 2 standard deviations above control mean. $\mathrm{N}$ : normal. $\mathrm{D}^{*}$ : diabetic glucose tolerance test (Joslin Clinic criteria ${ }^{5}$ ). $\mathrm{D}+$ : diabetic glucose tolerance test (American Diabetic Association criteria ${ }^{6}$ ).

who had an oral glucose tolerance test.

Values given in the text are mean \pm S.D.

Results were analysed by Student's test for unpaired data.

\section{Results (Table)}

The mean fasting serum trypsin for the patients $(196 \pm 76 \mu \mathrm{g} / \mathrm{l}$ was significantly lower than for controls (269 $\pm 714 \mu \mathrm{g} / 1)(\mathrm{P}<0.005$, Fig. 1) and this difference was maintained after a Lundh meal (Fig. 1). Five of the 28 patients $(18 \%)$ had a fasting trypsin below the normal range. After a Lundh meal the serum trypsin fell in the patient group and rose in the control group (Fig. 1). Five of the 14 patients had reduced trypsin levels (Fig. 2). The mean fasting serum glucose for the patients $(3.8 \pm 0.42 \mathrm{mmol} / \mathrm{l})$ was significantly greater than the control mean $(3.41 \pm 0.42 \mathrm{mmol} / \mathrm{l}, \mathrm{P}<0.05$, Fig. 3). After $100 \mathrm{~g}$ of glucose orally, the mean serum glucose for the two groups did not differ till 180 minutes when the patient mean was $5.26 \pm 1.58$ and the control mean was $3.96 \pm 1.45 \mathrm{mmol} / \mathrm{l}(\mathrm{P}<0.05)$. Eight patients and two controls were diabetics according to the Joslin clinical criteria ${ }^{5}$ of a blood glucose greater than 8.89 $\mathrm{mmol} / \mathrm{l}$ after $100 \mathrm{~g}$ oral glucose. Only three patients

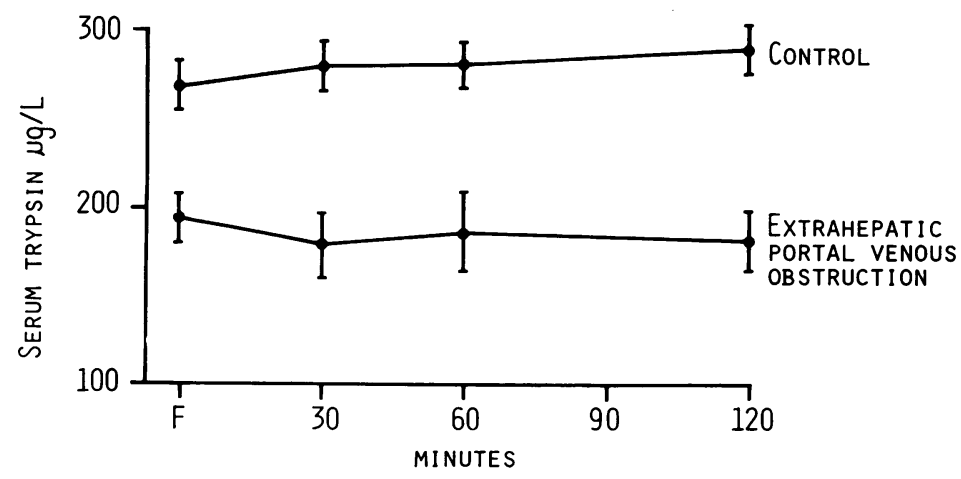

Fig. 1 Serum trypsin concentrations after a Lundh meal in extrahepatic portal venous obstruction and control subjects. Values are mean $\pm S E M$ (fasting: $\mathrm{P}<0.05 ; 30$ minutes: $\mathrm{P}<0.005 ; 60$ minutes: $\mathrm{P}<0.025)$. 


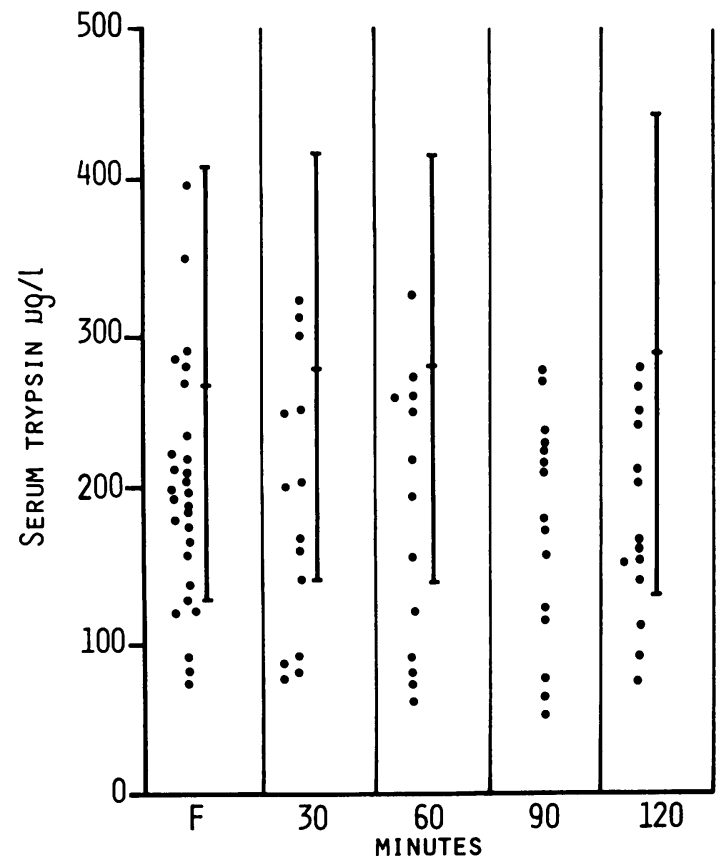

Fig. 2 Serum trypsin concentration after a Lundh meal in patients with extrahepatic portal venous obstruction. $V e r t i c a l$ bars represent control mean $\pm 2 S D$. A normal range was not established for the 90 minute value.

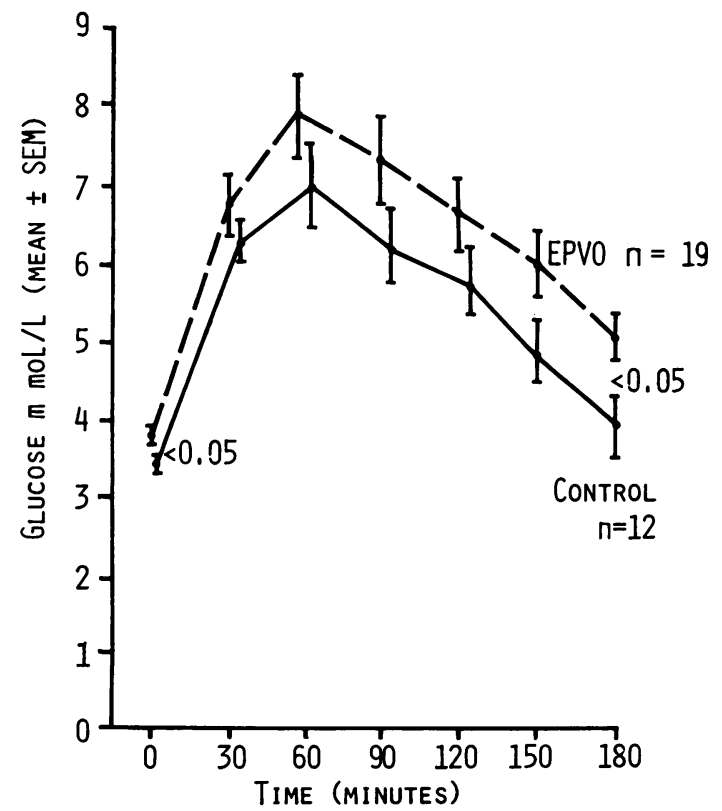

Fig. 3 Blood glucose after $100 \mathrm{~g}$ oral glucose in extrahepatic portal venous obstruction and in control subjects. Values are mean $\pm S E M$.

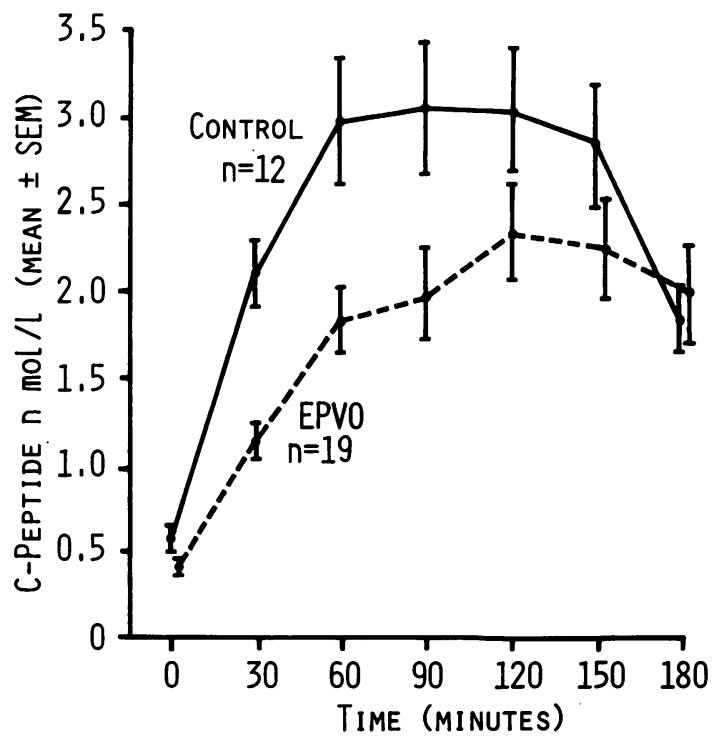

Fig. 4 C-peptide response after $100 \mathrm{~g}$ oral glucose in extrahepatic portal venous obstruction and control subjects. Values are mean $\pm S E M(30$ minutes: $\mathrm{P}<0.001 ; 60$ minutes: $\mathrm{P}<0.005)$.

and one control were diabetic if the American Diabetic Association ${ }^{6}$ rules of a blood glucose greater than $8.89 \mathrm{mmol} / \mathrm{l}$ at one hour and $7.77 \mathrm{mmol} / \mathrm{l}$ at two hours after $100 \mathrm{~g}$ oral glucose were applied. The mean fasting $\mathrm{C}$-peptide for the patients and the controls was the same, whereas at 30 and 60 minutes after the oral glucose the patients' values were lower ( $P<0.001, P<0.005$, Fig. 4).

Grey-scale ultrasonography of the pancreas was normal in 21 patients. One patient (No. 23, Table) who was diabetic according to Joslin Clinical Criteria had an ultrasound scan suggestive of chronic pancreatitis. The fasting serum trypsin was normal in this patient.

\section{Discussion}

Serum trypsin is a useful screening test for pancreatic disease. $^{7-9}$ If levels are subnormal then chronic pancreatitis or carcinoma of the pancreas is usually present. ${ }^{7}$ However, patients with chronic pancreatitis can have a normal serum trypsin. ${ }^{7-9}$ The low results found in five of our patients suggest pancreatic dysfunction. An enteropancreatic circulation for trypsin was originally demonstrated in rabbits ${ }^{1011}$ and probably exists in man as large amounts of trypsin are found in portal blood..$^{12}$ If this is so, then interruption of the portal circulation could affect the serum trypsin value. This might explain the low fasting levels in our patients. The same mechanism 
might also be expected to influence serum trypsin levels after pancreatic stimulation. However, pancreatic hyposecretion would also explain the fall in in serum trypsin which occurred in the patients after a meal, compared with the small rise in controls. Pro-insulin is cleaved in the pancreatic B-cell to insulin and C-peptide, which are released into the circulation in equimolar quantities..$^{13} \mathrm{C}$-peptide is not degraded by the liver and peripheral levels are a good reflection of pancreatic insulin secretion. The low values in our patients suggest that pancreatic insulin secretion is reduced. Peripheral insulin levels were also lower than control values, although the difference was not significant. Ligation of pancreatic venous drainage in dogs results in pancreatitis. ${ }^{14}$ Abnormalities in pancreatic pathology including hyperaemia, fibrosis and fat necrosis have been described after portal vein obstruction in man. ${ }^{15}$ Mass. Gen. Hosp. Case No. 38272 (1952). This results from chronic pancreatic venous congestion. ${ }^{16}$

In addition, the obstruction in the main portal vein may extend into the intrapancreatic veins and so lead to minor degrees of fibrosis and pancreatic dysfunction. The abdominal pain associated with extrahepatic portal venous obstruction could be explained in this way. ${ }^{17}$ Chronic pancreatitis can cause portal vein obstruction..$^{18}$ However, this is an unlikely cause as 20/29 patients had a known alternative aetiology for their portal venous obstruction, In the remaining nine, the clinical features did not support the diagnosis of primary chronic pancreatitis.

Invasive pancreatic investigations were not considered to be justified in symptom-free volunteer patients and endoscopic pancreatography was not performed. Similarly, duodenal intubation with measurement of trypsin output was not performed, as many of the patients had documented oesophageal varices. Duodenal intubation is an insensitive test of pancreatic function and will not detect pancreatic hypofunction of minimal degree. Furthermore, in minimal pancreatic disease, pancreatic secretion is increased. ${ }^{19}$ Normal grey-scale ultrasonography excluded gross pancreatic pathology.

Thus the changes observed in these patients could be the result of the abnormal portal circulation or mild pancreatic damage secondary to chronic venous congestion. An intact portal circulation is necessary for glucose homeostasis in both $\operatorname{man}^{20}$ and animals $^{21}$ and may also be necessary for trypsin homeostasis.

Over $75 \%$ of the pancreas needs to be destroyed ${ }^{22}$ and pancreatic lipase output to fall below $10 \%$ of normal ${ }^{19}$ for clinical pancreatic insufficiency to develop, and it is not surprising that our patients showed none of the usual features of chronic pan- creatitis. However, minimal pancreatic dysfunction has been demonstrated. Patients with extrahepatic portal venous obstruction who suffer from severe abdominal pain, steatorrhoea, or failure to thrive should have their pancreatic function fully investigated.

The authors thank Dr L A Berger for performing grey-scale ultrasonography, Hoechst for providing the trypsin radioimmunoassay kits, and $\operatorname{Dr} \mathrm{O} \mathrm{K}$ Faber for performing C-peptide and insulin assays. LJW and GL-B are in receipt of MRC training fellowships, GS-L is supported by the Ingram Trust.

\section{References}

${ }^{1}$ Thompson EN, Williams R, Sherlock S. Liver function in extrahepatic portal hypertension. Lancet 1964; 2: 1352-6.

${ }^{2}$ Lundh G. Pancreatic exocrine function in neoplastic and inflammatory disease: a simple and reliable new test Gastroenterology 1962; 42: 275-80.

${ }^{3}$ Heding LG. Determination of total serum insulin (IRI) in insulin treated diabetic patients. Diabetologia 1972; 8: $260-6$.

${ }^{4}$ Heding LG. Radioimmunological determination of human C-peptide in serum. Diabetologia 1975; 11: 541-8.

${ }^{5}$ Marble A. Joslin's diabetes mellitus. Eds A. Marble, P. White, R. F. Bradley, and L. P. Krall. Philadelphia: Lea and Febiger, 1971: 1202.

${ }^{6}$ McDonald GW, Fisher GF, Burnham C. Reproducibility of the oral glucose tolerance test. Diabetes 1965; 14: 473-80.

${ }^{7}$ Elias E, Redshaw M, Wood T. Diagnostic importance of changes in circulating concentrations of ummunoreactive trypsin. Lancet 1977; 2: 66-8.

${ }^{8}$ Adrian TE, Besterman HS, Mallinson CN, Galorotis C, Bloom SR. Plasma trypsin in the diagnosis of steatorrhoea due to chronic pancreatitis (Abstract). Gut 1978; 19: A446.

${ }^{9}$ Lake-Bakaar G, McKavanagh S, Wood T, Redshaw M, Summerfield JA, Elias E. Serum immunoreactive trypsin concentration following a Lundh meal: its value in the diagnosis of pancreatic disease. $J$ Clin Pathol 1979; 32: 1003-8.

${ }^{10}$ Götze H, Rothman SS. Enteropancreatic circulation of digestic enzyme as a conservative mechanism. Nature 1975; 257: 607-9.

${ }^{11}$ Liebow C, Rothman SS. Enteropancreatic circulation of digestive enzymes. Science 1975; 189: 472-4.

${ }^{12}$ Lake-Bakaar G, Smith-Laing G, Summerfield JA. Origin of serum trypsin: evidence for intestinal reabsorption (Abstract). Gut 1978; 19: A445.

${ }^{13} \mathrm{Kitabchi}$ AE. Proinsulin and C-peptide: review. Metabolism 1977; 26: 547-87.

${ }^{14}$ Adams TW, Musselman MM. Pancreatic venous thrombosis as an etiologic factor in acute necrotizing hemorrhagic pancreatitis. Surg Forum 1953; 4: 401-6. ${ }^{15}$ Sanford HL, Dolley DH. A clinical and pathological 
report of a case of splenic anaemia. Am J Med Sci 1905; 129: 798-813.

${ }^{16}$ Fraser J, Brown AK. Clinical syndrome associated with a rare anomaly of vena portae system. Surg Gynecol Obstet 1944; 78: 520-4.

${ }^{17}$ Gibson JB, Richards RL. Cavernous transformation of the portal vein. $J$ Pathol 1955 ; 70: 81-96.

${ }^{18}$ Longstreth GF, Newcomer AD, Green PA. Extrahepatic portal hypertension caused by chronic pancreatitis. Ann Intern Med 1971; 75: 903-8.

${ }^{19}$ Dreiling, DA, Bordalo O. Secretory patterns in minimal pancreatic inflammatory pathologies. Am $J$ Gastroenterol 1973; 60: 60-9.

${ }^{20}$ Weglicki WB, Ganda OP, Soeldner JS, Murawski BJ, Cohn LH. Portacaval diversion for severe hypercholesterolemia. Arch Surg 1977; 112: 634-6.

${ }^{21}$ Sells RA, Calne RY, Hadjiyanakis V, Marshall VC. Glucose and insulin metabolism after pancreatic transplanation. Br Med J 1972; 3: 678-81.

${ }^{22}$ Kalser MH, Leite, Warren WD. Fat assimilation after massive distal pancreatectomy. N Engl J Med 1968; 279: 570-6. 